\title{
Penentuan Status Kewaspadaan COVID-19 Pada Suatu Wilayah Menggunakan Metode Fuzzy Inference System (FIS) Mamdani
}

\author{
Adella Septiana Mugirahayu ${ }^{1, *}$, Lilik Linawati ${ }^{1}$, Adi Setiawan ${ }^{1}$ \\ ${ }^{1}$ Jurusan Matematika, Departemen Matematika, Fakultas Sains dan Matematika, Universitas Kristen Satya \\ Wacana, Salatiga, Jawa Tengah 50711 \\ *email korespondensi: $\underline{62017002 @ s t u d e n t . u k s w . e d u}$
}

Received : 16 Desember 2020; Revised : 11 Februari 2021; Accepted : 11 Maret 2021; Published : 1 April 2021

\begin{abstract}
ABSTRAK
Pada tahun 2020, Indonesia menjadi salah satu negara yang mengalami pandemi Coronavirus Disease 19 (COVID-19) akibat virus SARS-CoV-2. Mengatasi hal tersebut, pemerintah harus menetapkan kebijakan yang efektif dengan memperhatikan situasi dan kondisi setiap daerah. Salah satu caranya adalah dengan menentukan status kewaspadaan. Di Indonesia, status kewaspadaan wilayah diserahkan pada kebijakan pemerintah daerah masingmasing yang menyebabkan adanya penilaian secara subjektif oleh pemerintah daerah,sehingga banyak definisi dan batasan yang kurang jelas mengenai penentuan status kewaspadaan. Permasalahan tersebutlah yang melatarbelakangi penelitian ini, dimana akan dicari suatu model berdasarkan metode Fuzzy Inference System (FIS) Mamdani untuk menentukan status kewaspadaan COVID-19 berdasarkan variabel terkait dan aturan yang berlaku. Data yang digunakan adalah data harian COVID-19 Provinsi Jawa Barat (1 April - 15 Juli 2021). Data yang digunakan berjumlah 27 kelompok data wilayah yang terdiri dari 4 variabel. Variabel inputnya adalah kasus positif COVID-19, kasus Orang dalam Pemantauan (ODP), dan kasus Pasien dalam Pemantauan (PDP), dan masing-masing variabel didefinisikan menjadi 5 himpunan Fuzzy, yaitu Sangat Rendah, Rendah, Sedang, Tinggi, dan Sangat Tinggi. Variabel output-nya didefinisikan dalam 5 himpunan Fuzzy tentang Status Kewaspadaan seperti peraturan Pemda Jabar yaitu status HIJAU, BIRU, KUNING, MERAH, dan HITAM. Semua variabel menggunakan fungsi keanggotaan representasi kurva segitiga. Proses analisis data menggunakan software Matlab. Keberhasilan model dinilai dari persentase kesamaan status yang diperoleh dengan membandingkan hasil analisis FIS Mamdani dengan data status kewaspadaan real. Setelah melakukan 4 kali pengulangan analisis, dimana pada setiap analisis dilakukan perubahan domain pada himpunan Fuzzy, didapatkan model dengan persentase kesamaan status rata-rata sebesar $81 \%$, pada data 6 wilayah di Jawa Barat.
\end{abstract}

Kata-kata kunci: aturan implikasi; COVID-19; FIS Mamdani; himpunan Fuzzy; status kewaspadaan

\section{PENDAHULUAN}

Pada tahun 2020, negara Indonesia mengalami pandemi akibat suatu penyakit bernama Coronavirus Disease 19 (COVID-19). COVID-19 merupakan penyakit yang menyerang sistem pernafasan dan bersifat menular. Penyakit ini disebabkan oleh virus bernama Severe Acute Respiratory Syndrome Coronavirus 2 (SARS-CoV-2). Kepastian bahwa Indonesia sudah terinfeksi virus corona bermula pada tanggal 2 Maret 2020, dimana ditemukan adanya kasus positif COVID-19 di Depok, Jawa Barat (Susilo dkk., 2020). Kemudian, beberapa hari setelahnya, banyak kasus-kasus positif lain yang bermunculan. Tercatat sampai bulan November, di Indonesia sendiri telah memiliki sekitar 400.000 lebih kasus positif COVID-19 (John Hopkins University \& Medicine, 2020).

Dalam mengatasi pandemi COVID-19, pemerintah Indonesia sesegera mungkin menerapkan berbagai langkah kebijakan seperti social distancing, pembelajaran dan bekerja secara daring, kewajiban pemakaian masker, dan masih banyak lagi (Tuwu, 2020). Dalam penerapan kebijakan-kebijakan tersebut, tentunya pemerintah perlu memperhatikan situasi dan kondisi masing-masing daerah. Salah satu caranya adalah dengan adanya penetapan status kewaspadaan di setiap daerah, untuk memutus rantai penularan COVID-19. Status kewaspadaan atau zona warna COVID-19 adalah pembagian daerah menjadi beberapa warna dengan tujuan untuk memantau situasi dan kondisi secara dinamis, dan meningkatkan berbagai tindakan apabila diperlukan (Shen, Bar-yam, \& New England Complex Systems Institute, 2020).

Di Indonesia, pengaturan status kewaspadaan tingkat daerah diserahkan pada pemerintah daerah masing-masing. Hal ini menyebabkan adanya penilaian secara subjektif oleh kepala daerah yang berimbas 
pada banyaknya definisi dan batasan yang kurang jelas mengenai penentuan status kewaspadaan. Akibatnya, pemerintah sulit dalam memberikan kebijakan yang tepat, cepat, serta efektif. Dari situasi tersebut, maka diperlukan adanya suatu perhitungan matematis di dalam memecahkan permasalahan tersebut. Dimana, penentuan status kewaspadaan dapat dimodelkan secara matematis berdasarkan parameter atau variabel yang tepat, namun tetap sesuai dengan keadaan tiap daerah atau wilayah. Situasi tersebutlah yang melatarbelakangi penelitian ini, dimana akan dicari suatu model matematis berdasar metode Fuzzy Inference System (FIS) Mamdani untuk menentukan status kewaspadaan COVID-19.

Sampai saat ini, penelitian mengenai penentuan status kewaspadaan COVID-19 pada suatu wilayah belum dijumpai. Namun, terdapat penelitian yang mendukung atau menjadi referensi penelitian ini, seperti penelitian oleh Saiful Arifin, Much Aziz Muslim, dan Sugiman tentang implikasi logika Fuzzy Mamdani untuk mendeteksi status kerentanan banjir di wilayah Semarang Utara. Penelitian ini berisi analisis implementasi logika Fuzzy Mamdani untuk menentukan apakah wilayah Semarang Utara termasuk wilayah aman akan banjir, rawan akan banjir, atau pasti akan mengalami banjir menggunakan variabel input kepadatan penduduk, kelerengan, drainase,dan lain sebagainya. Berdasarkan penelitian tersebut, diketahui bahwa wilayah Bulu Lor sebagai salah satu wilayah yang dianalisis termasuk dalam wilayah "Banjir" (Arifin dkk., 2016). Selain itu, terdapat penelitian oleh Yusli Yenni dan Intan Utnasari tentang penentuan tingkat kriminalitas pada suatu wilayah menggunakan metode Fuzzy Logic Mamdani. Berdasarkan penelitian tersebut, diketahui bahwa wilayah Batam sebagai objek analisis termasuk dalam wilayah dengan tingkat kriminalitas "Rendah" (Yenni \& Utnasari, 2019).

Kedua penelitian tersebut menggunakan metode yang sama yaitu Logika Fuzzy, khususnya metode Fuzzy Inference System (FIS) Mamdani. Fuzzy logic atau logika Fuzzy sendiri merupakan suatu logika multi nilai yang bisa memrepresentasikan keadaan di dunia nyata. Logika Fuzzy juga merupakan logika yang memiliki nilai kekaburan atau kesamaran (Fuzzyness) antara benar dan salah. Jika pada logika konvensional, suatu elemen mempunyai dua pilihan nilai kebenaran dalam himpunan yaitu terdapat dalam himpunan (bernilai $1 \rightarrow$ BENAR) atau tidak terdapat dalam himpunan (bernilai $0 \rightarrow$ SALAH ). Pada logika Fuzzy, dikenal adanya derajat kebenaran yang berada pada interval [0,1] (Zadeh, 1965). Logika Fuzzy juga dapat digambarkan sebagai kotak penghubung antara ruang input dan ruang output. Kotak yang dimaksud berisi metode-metode dalam Logika Fuzzy yang digunakan untuk mengolah data input menjadi output. (Kusumadewi \& Purnomo, 2010). Salah satu metode yang dapat digunakan adalah Fuzzy Inference System (FIS) atau sistem inferensi Fuzzy yakni sistem yang mencakup proses pemetaan dari masukan (input) yang diberikan menjadi keluaran (output) dengan menggunakan logika Fuzzy. Oleh karena itu, didalam FIS minimal terdapat dua hal yakni input dan output (Niemiec, 2017). Metode-metode FIS ada beberapa macam, salah satunya adalah metode Mamdani.

Metode FIS Mamdani dapat disebut juga sebagai metode Min-Max. Dalam metode ini, setiap aturan berbentuk implikasi. Pada setiap aturan implikasi di metode Mamdani, anteseden akan mempunyai nilai keanggotaan berbentuk minimum $(\mathrm{min})$, sedangkan konsekuennya akan memiliki nilai keanggotaan berbentuk maksimum ( $\max$ ) (Setiadji, 2009). Menurut Kusumadewi dan Purnomo, dalam menyelesaikan permasalahan menggunakan metode FIS Mamdani, terdapat beberapa tahapan yang perlu dilakukan. Pertama, membentuk himpunan Fuzzy untuk setiap variabel beserta domainnya masing-masing. Kedua, membuat aturan implikasi yang mengkombinasikan semua variabel yang digunakan. Ketiga, melakukan komposisi aturan dengan menggunakan metode maksimum untuk mendapatkan Fuzzy set tunggal. Keempat, melakukan proses defuzzyfikasi yakni memetakan besaran Fuzzy ke dalam bentuk nilai tegas (Kusumadewi \& Purnomo, 2010).

Berdasarkan pembahasan diatas dan dukungan hasil penelitian-penelitian, maka dilakukanlah penelitian yang berjudul "Penentuan Status Kewaspadaan COVID-19 pada Suatu Wilayah Menggunakan Metode Fuzzy Inference System (FIS) Mamdani" ini. Tujuan utama penelitian ini adalah mendapatkan model berdasarkan FIS Mamdani untuk menentukan status kewaspadaan terhadap COVID-19 di suatu wilayah berdasarkan variabel-variabel input, yaitu: kasus positif COVID-19, kasus Orang dalam Pemantauan (ODP), dan kasus Pasien dalam Pemantauan (PDP), dan variabel output: status kewaspadaan, serta aturan yang berlaku di wilayah bersangkutan. 


\section{EKSPERIMEN}

\section{Data Penelitian}

Jenis data yang dikumpulkan adalah data sekunder. Data sekunder merupakan sumber data penelitian yang diperoleh melalui media perantara atau secara tidak langsung yang berupa buku, catatan, bukti yang telah ada, atau arsip baik yang dipublikasikan maupun yang tidak dipublikasikan secara umum. Pada penelitian ini, digunakan data pandemi COVID-19 di Provinsi Jawa Barat. Data tersebut merupakan data real oleh Dinas Kesehatan Jawa Barat dan juga Pemerintah Provinsi Jawa Barat yang di publikasikan dan dapat diakses secara umum melalui situs dan aplikasi resmi bernama PIKOBAR (Pusat Informasi dan Koordinasi COVID-19 Jawa Barat).

Penelitian ini juga dilakukan dengan memperhatikan berbagai macam kebijakan pemerintah pusat maupun daerah yang berhubungan dengan pandemi COVID-19 seperti protokol kesehatan, status kewaspadaan, dan sebagainya pada wilayah daerah yang diteliti. Data yang digunakan dalam penelitian merupakan data COVID-19 dari berbagai wilayah di Jawa Barat yang terdiri dari 16 wilayah kabupaten dan 9 wilayah kota. Data tersebut merupakan data harian mulai tanggal 1 April 2020 sampai tanggal 15 Juli 2020 (109 hari). Data yang digunakan terdiri dari data kasus positif, data Orang Dalam Pemantauan (ODP), data Pasien dalam Pemantauan (PDP), dan data status kewaspadaan. Sehingga, total data yang digunakan adalah 25 set data wilayah, dimana setiap set terdiri dari 4 data variabel, dan setiap variabel terdiri dari 109 datum. Berikut merupakan beberapa penjelasan mengenai data yang digunakan.

1. Data status kewaspadaan COVID-19

Provinsi Jawa Barat terdiri dari beberapa wilayah yang memiliki status kewaspadaan masingmasing yang menggambarkan kondisi pandemi COVID-19 di wilayah tersebut. Pemerintah Provinsi Jawa Barat sendiri membagi status kewaspadaan menjadi 5 tingkat, dimana di setiap status akan memiliki kebijakan-kebijakan yang menjadi pedoman kegiatan maupun operasional untuk berbagai tempat. Hal tersebut dituliskan pada Peraturan Gubernur Jawa Barat No.46 Tahun 2020 tentang Pedoman Pembatasan Sosial Berskala Besar Secara Proporsional Sesuai Level Kewaspadaan Daerah Kabupaten/Kota Sebagai Persiapan Pelaksanaan Adaptasi Kebiasaan Baru Untuk Pencegahan dan Pengendalian Coronavirus Disease 2019 (COVID-19). Kelima status tersebut adalah sebagai berikut :

a. HIJAU : Merupakan status kewaspadaan level 1 atau yang paling rendah. Status ini menggambarkan kondisi paling normal dimana kasus positif berjumlah sangat sedikit atau bahkan tidak ada sama sekali. Pada status kewaspadaan ini, pemerintah juga akan menerapkan beberapa kebijakan yang masih bersifat longgar.

b. BIRU : Merupakan status kewaspadaan level 2 atau moderat. Status ini menggambarkan kondisi dimana kasus positif sedikit dan hanya disebabkan kasus impor dan penularan lokal. Pada status kewaspadaan ini, pemerintah memberi kebijakan dengan batasan yang sedikit lebih ketat.

c. KUNING : Merupakan status kewaspadaan level 3 atau cukup berat. Status ini menggambarkan kondisi dimana kasus positif cukup banyak terjadi, misalnya ditemukan kasus COVID-19 pada klaster tunggal.

d. MERAH : Merupakan status kewaspadaan level 4 atau berat. Status ini menggambarkan adanya kasus positif yang cukup meluas dan banyak, misalnya kasus positif pada satu atau lebih kluster dan meningkat setiap harinya. Pada status kewaspadaan ini, pemerintah menutup banyak tempat maupun instansi seperti lembaga permasyarakatan, stasiun, terminal, bandara, tempat ibadah, dan sebagainya.

e. HITAM : Merupakan status kewaspadaan level 5 atau kritis. Status ini menggambarkan kondisi dimana kasus positif sudah tidak terkendali dengan adanya penularan pada komunitas besar. Pada status kewaspadaan ini, pandemi COVID-19 semakin meluas dan tidak terkendali. Pemerintah juga akan menerapkan kebijakan, dimana hampir semua tempat dan instansi dilarang beroperasi.

2. Data kasus positif COVID-19 : Merupakan kasus dimana seseorang sudah terinfeksi dan dikonfirmasi positif COVID-19.

3. Data jumlah Orang dalam Pengawasan (ODP) : Orang dalam Pengawasan merupakan istilah yang digunakan untuk orang-orang yang diawasi karena memiliki gejala COVID-19 seperti demam atau mengalami gangguan pernafasan ringan. Selain itu, ODP juga mencakup orang-orang yang pernah mengunjungi atau tinggal di daerah yang terinfeksi virus corona. 
4. Data jumlah Pasien dalam Pengawasan (PDP) : Pasien Dalam Pemantauan merupakan orang yang sudah dirawat oleh tenaga kesehatan (menjadi pasien) dan menunjukkan gejala COVID-19 seperti sakit seperti demam, batuk, pilek, dan sesak napas.

\section{Prosedur Kerja}

a. Tahap Pengumpulan Data

Data terkait pandemi COVID-19 Provinsi Jawa Barat diperoleh dengan cara mengunduh melalui situs dan aplikasi resmi Pikobar (Pusat Informasi dan Koordinasi Covid-19 Jabar). Selain itu, dalam pengambilan data juga memperhatikan dan memahami aturan terkait pandemi dalam berbagai keputusan dan peraturan.

b. Tahap Pengolahan Data

1. Mengidentifikasi variabel input dan variabel output berdasarkan data COVID-19 yang diperoleh.

2. Membentuk himpunan Fuzzy untuk setiap variabel yang sudah ditentukan. Setiap variabel tersebut didefinisikan sebagai variabel linguistik dan setiap himpunan Fuzzy yang dibentuk adalah sebagai nilai linguistiknya. Setiap himpunan Fuzzy juga ditentukan pula batas-batas atau domainnya masingmasing.

3. Menyelesaikan model yang dibuat dengan menggunakan Fuzzy Toolbox dalam software Matlab. Dalam tahap ini akan ditentukan pula metode inferensi yang digunakan. Selain itu, ditentukan pula metode implikasi, agregasi, dan defuzzyfikasinya.

4. Setelah model selesai dibuat, dilakukan implementasi model menggunakan data tersebut.

5. Hasil implementasi model pada data, dapat diketahui status kewaspadaan COVID-19 untuk setiap wilayah yang diteliti. Apabila terdapat hasil yang menunjukkan bahwa suatu wilayah masuk kedalam dua status kewaspadaan sekaligus, maka akan dihitung derajat keanggotaannya di kedua himpunan Fuzzy status kewaspadaan tersebut. Perhitungan ini dapat menggunakan rumus fungsi keanggotaan pada representasi kurva segitiga:

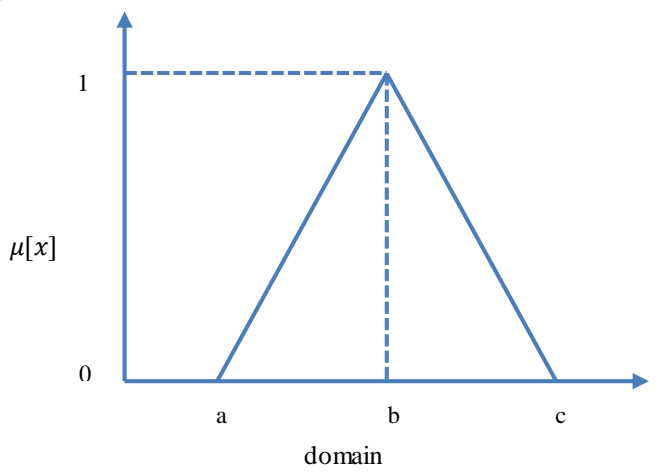

Gambar 1. Representasi Fungsi Keanggotaan Kurva Segitiga

Pada representasi kurva segitiga, fungsi keanggotaan atau $\mu(x)$ dapat dirumuskan seperti :

$$
\mu(x)= \begin{cases}0 ; & x \leq a \\ \frac{(x-a)}{(b-a)} ; & a<x<b \\ 1 ; & x=b \\ \frac{(c-x)}{(c-b)} ; & b<x<c \\ 0 ; & x \geq c\end{cases}
$$

Setelah didapatkan kedua derajat keanggotaan, status kewaspadaan yang dipilih untuk dibandingkan dengan data real di langkah poin 6 adalah status kewaspadaan dari derajat keanggotaan yang lebih tinggi.

6. Dilakukan perbandingan antara status kewaspadaan hasil implementasi data pada model dengan data status kewaspadaan real untuk menentukan baik atau tidaknya model dalam menentukan status kewaspadaan. 
7. Baik atau tidaknya model dapat dilihat melalui tingkat kesamaan antara hasil FIS Mamdani dan data real yang dinyatakan dalam bentuk persentase $(\mathrm{p} \%)$. Perhitungan presentase dilakukan dengan rumus (2):

$$
\text { Persentase Kesamaan }(\mathrm{p} \%)=\frac{\text { Jumlah Data yang Sama }}{\text { Jumlah Keseluruhan Data }} \times 100 \%
$$

Pada penelitian ini, diberlakukan indikator untuk melihat keberhasilan model berupa rata-rata persentase kesamaan adalah minimal $80 \%$.

8. Apabila kesamaan antara hasil FIS Mamdani dan data real belum mencapai $80 \%$, maka akan dilakukan perubahan pada domain-domain himpunan Fuzzy maupun aturan implikasi. Setelah itu, dilakukan implementasi model yang baru terhadap data kembali seperti pada langkah nomor 4.

9. Indikator keberhasilan model yaitu apabila dicapai kesamaan status antara hasil FIS Mamdani dan data real setidaknya $80 \%$, maka proses pengolahan data dihentikan.

\section{HASIL DAN DISKUSI}

\section{Hasil Analisis Data}

Untuk pendefinisian variabel input dan output, dalam hal menentukan batas - batas domain himpunan Fuzzy, digunakan data keseluruhan wilayah Jawa Barat. Sedangkan untuk implementasi model, dilakukan pada data wilayah-wilayah besar di Jawa Barat yaitu Kabupaten Bogor, Kota Depok, Kota Bandung, Kabupaten Cianjur, Kabupaten Garut, dan Kota Bekasi.

Dalam penelitian ini, dilakukan analisis FIS Mamdani sebanyak 4 kali yang akhirnya dicapai indikator $80 \%$. Pada setiap analisis atau iterasi, dilakukan tindakan terhadap model dengan mengubah-ubah domain himpunan Fuzzy setiap variabel. Kemudian, untuk aturan implikasinya ditentukan pada analisis pertama dan tidak dilakukan perubahan pada analisis-analisis selanjutnya. Berikut disajikan hasil pengolahan data pada analisis yang keempat :

a. Himpunan Fuzzy dari setiap variabel input dan output

1. Variabel input jumlah kasus positif COVID-19

Tabel 1 akan menunjukkan himpunan-himpunan Fuzzy yang dibuat untuk variabel kasus positif COVID-19 beserta domainnya.

Tabel 1. Himpunan Fuzzy Variabel Positif COVID-19

\begin{tabular}{lc}
\hline \multicolumn{1}{c}{ Himpunan Fuzzy } & Domain \\
\hline Sangat Rendah & {$[0,100]$} \\
Rendah & {$[50,200]$} \\
Sedang & {$[150,350]$} \\
Tinggi & {$[275,435]$} \\
Sangat Tinggi & {$[375,+\infty]$} \\
\hline
\end{tabular}

Dari Tabel 1, dapat dilihat bahwa pada variabel kasus positif COVID-19 didefinisikan 5 himpunan Fuzzy yakni Sangat Rendah, Rendah, Sedang, Tinggi, dan Sangat Tinggi. Kemudian menggunakan fungsi keanggotaan segitiga disajikan pada Gambar $\mathbf{2}$.

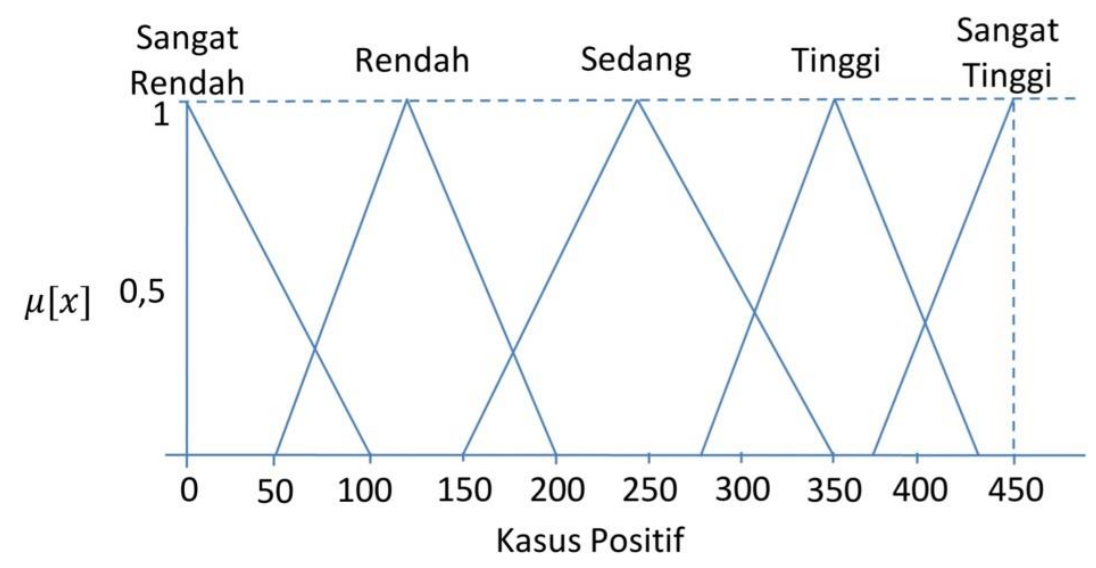

Gambar 2. Himpunan Fuzzy padaVariabel Kasus Positif 
2. Variabel input Pasien Dalam Pengawasan (PDP)

Tabel $\mathbf{2}$ dan Gambar $\mathbf{3}$ menunjukkan himpunan-himpunan Fuzzy yang dibuat untuk variabel PDP beserta domainnya. Fungsi keanggotaan yang digunakan adalah representasi kurva segitiga.

Tabel 2. Himpunan Fuzzy Variabel PDP

\begin{tabular}{lc}
\hline \multicolumn{1}{c}{ Himpunan Fuzzy } & Domain \\
\hline Sangat Rendah & {$[0,172]$} \\
Rendah & {$[60,365]$} \\
Sedang & {$[243,565]$} \\
Tinggi & {$[450,765]$} \\
Sangat Tinggi & {$[650,+\infty]$} \\
\hline
\end{tabular}

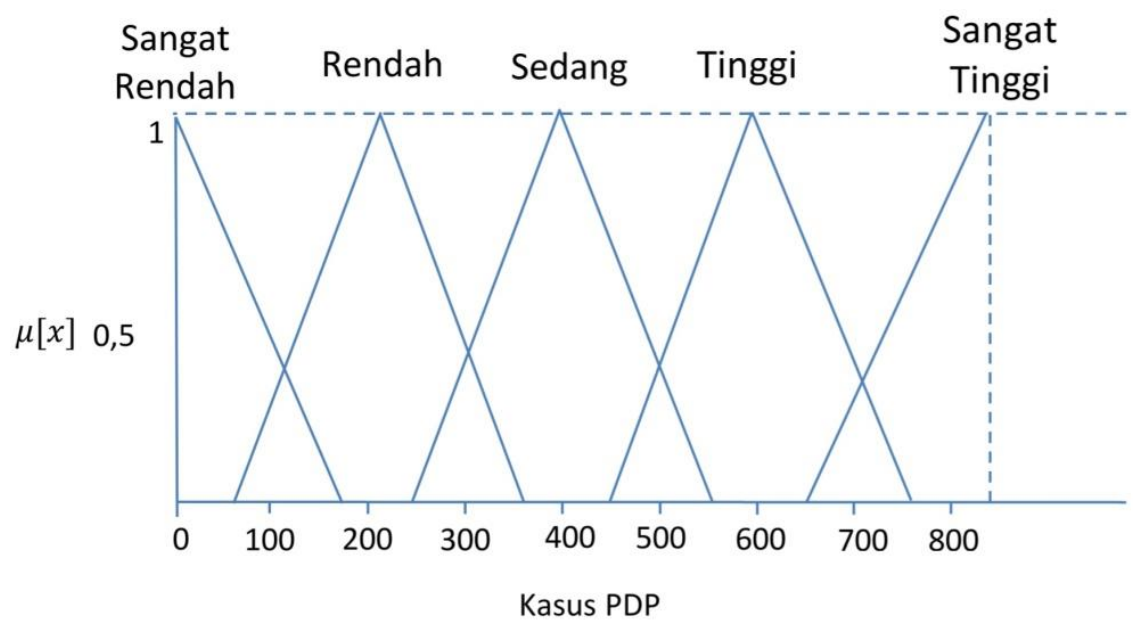

Gambar 3 Himpunan Fuzzy Variabel PDP

3. Variabel input Orang Dalam Pengawasan (ODP)

Tabel 3 menunjukkan himpunan-himpunan Fuzzy yang dibuat untuk variabel ODP beserta domainnya.

Tabel 3. Himpunan Fuzzy Variabel ODP

\begin{tabular}{lc}
\hline \multicolumn{1}{c}{ Himpunan Fuzzy } & Domain \\
\hline Sangat Rendah & {$[0,400]$} \\
Rendah & {$[180,1020]$} \\
Sedang & {$[700,1505]$} \\
Tinggi & {$[1202,2000]$} \\
Sangat Tinggi & {$[1800,+\infty]$} \\
\hline
\end{tabular}

Dari Tabel 3, dapat dilihat bahwa pada variabel ODP juga didefinisikan 5 himpunan Fuzzy yakni: Sangat Rendah, Rendah, Sedang, Tinggi, dan Sangat Tinggi, serta kurva segitiga sebagai fungsi keanggotaannya, seperti pada Gambar 4.

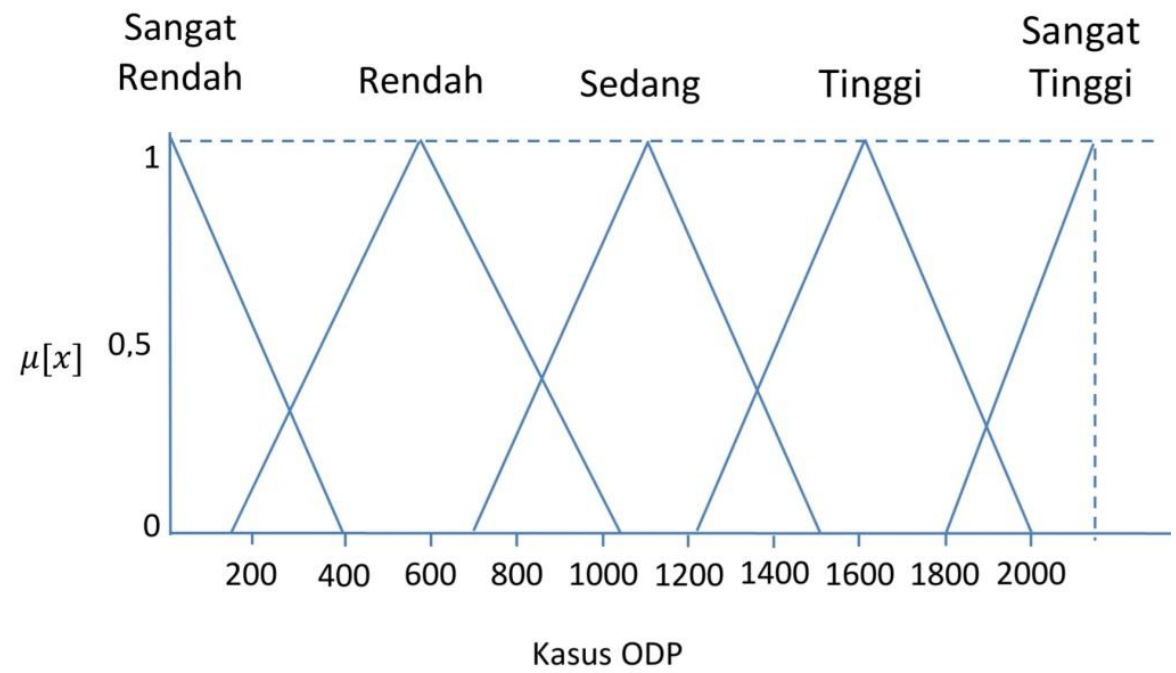

Gambar 4. Himpunan Fuzzy untuk Variabel ODP 
4. Variabel output status kewaspadaan COVID-19

Variabel status kewaspadaan terdiri dari status HIJAU, BIRU, KUNING, MERAH, dan HITAM. Pada penelitian ini, setiap status kewaspadaan yang dihasilkan akan menggambarkan kondisi wilayah berdasarkan variabel input yang digunakan (kasus positif, ODP, dan PDP). Status kewaspadaan ini dibuat dalam rentang nilai 0-10, dimana nilai akan didapat dari hasil perhitungan FIS Mamdani dengan melibatkan variabel input. Tabel 4 menunjukkan himpunan-himpunan Fuzzy yang dibuat untuk variabel status kewaspadaan beserta domainnya. Pada tabel tersebut juga terlihat dimana status HIJAU merupakan status yang paling rendah dan menggambarkan kondisi wilayah yang normal dan terkendali. Sedangkan status HITAM menjadi status paling kritis dan menggambarkan kondisi pandemi wilayah yang tidak terkendali.

Tabel 4. Himpunan Fuzzy Variabel Status Kewaspadaan

\begin{tabular}{lc}
\hline \multicolumn{1}{c}{ Himpunan Fuzzy } & Domain \\
\hline HIJAU & {$[0,2]$} \\
BIRU & {$[1,4.5]$} \\
KUNING & {$[3.5,7]$} \\
MERAH & {$[6,9]$} \\
HITAM & {$[8,10]$} \\
\hline
\end{tabular}

Dari Tabel 4, dapat dilihat bahwa variabel output yaitu status kewaspadaan juga didefinisikan 5 himpunan Fuzzy dengan masing-masing menggunakan kurva segitiga sebagai fungsi keanggotaannya, seperti disajikan pada Gambar 5.

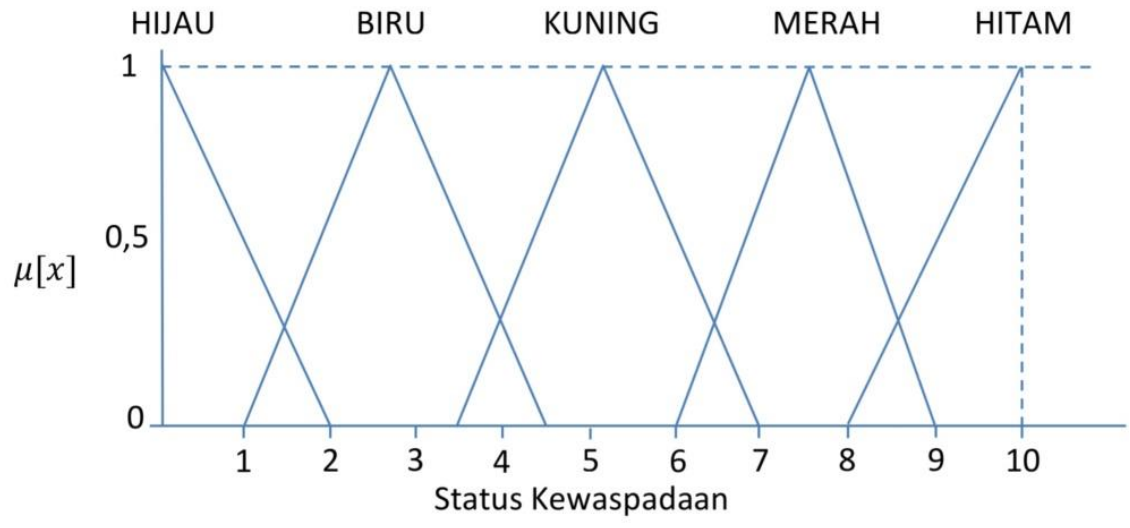

Gambar 5. Himpunan Fuzzy untuk Variabel Status Kewaspadaan

Dari Gambar 5 dapat diketahui bahwa fungsi keanggotaan yang digunakan adalah representasi kurva segitiga. Untuk lebih lengkapnya mengenai fungsi keanggotaan dari setiap himpunan Fuzzy pada variabel output Status Kewaspadaan dapat dilihat sebagai berikut :

- Fungsi Keanggotaan Himpunan Fuzzy HIJAU

$$
\mu_{\text {HUAU }}(x)= \begin{cases}0 ; & x \geq 2 \\ \frac{(2-x)}{2} ; & 0<x<2 \\ 1 ; & x=0\end{cases}
$$

- Fungsi Keanggotaan Himpunan Fuzzy BIRU

$$
\mu_{\text {BIRU }}(x)= \begin{cases}0 ; & x \leq 1 \\ \frac{(x-1)}{1,75} ; & 1<x<2,75 \\ 1 ; & x=2,75 \\ \frac{(4,5-x)}{1,75} ; & 2,75<x<4,5 \\ 0 ; & x \geq 4,5\end{cases}
$$


- Fungsi Keanggotaan Himpunan Fuzzy KUNING

$$
\mu_{\text {KUNING }}(x)= \begin{cases}0 ; & x \leq 3,5 \\ \frac{(x-3,5)}{1,75} ; & 3,5<x<5,25 \\ 1 ; & x=5,25 \\ \frac{(7-x)}{1,75} ; & 5,25<x<7 \\ 0 ; & x \geq 7\end{cases}
$$

- Fungsi Keanggotaan Himpunan Fuzzy MERAH

$$
\mu_{\text {MERAH }}(x)= \begin{cases}0 ; & x \leq 6 \\ \frac{(x-6)}{1,5} ; & 6<x<7,5 \\ 1 ; & x=7,5 \\ \frac{(9-x)}{1,5} ; & 7,5<x<9 \\ 0 ; & x \geq 9\end{cases}
$$

- Fungsi Keanggotaan Himpunan Fuzzy HITAM

$$
\mu_{\text {HITAM }}(x)= \begin{cases}0 ; & x \leq 8 \\ \frac{(x-8)}{2} ; & 8<x<10 \\ 1 ; & x=10\end{cases}
$$

b. Aturan Implikasi yang Digunakan

Karena terdapat 3 variabel input yang masing-masing mempunyai 5 himpunan Fuzzy, dan 1 variabel output dengan 5 himpunan Fuzzy juga, maka dapat dibuat aturan implikasinya sebanyak 625 aturan sebagai hasil kombinasi dari variabel dan himpunan-himpunan Fuzzy. Dari 625 aturan implikasi tidak dapat digunakan semuannya, perlu dilakukan penyaringan, khususnya untuk aturan implikasi yang secara logika sudah tidak dapat diterapkan seperti:

1) If POSITIF is Sangat Rendah, and PDP is Sangat Rendah, and ODP is Sangat Rendah, then STATUS is HITAM.

2) If POSITIF is Sangat Tinggi, and PDP is Tinggi, and ODP is Sangat Tinggi, then STATUS is HIJAU.

Dari hasil penyaringan aturan implikasi yang dapat dan sesuai untuk diterapkan, diperoleh 125 aturan implikasi yang digunakan dalam FIS Mamdani ini, diantaranya dapat dilihat pada Tabel $\mathbf{5}$.

Tabel 5. Beberapa Aturan Implikasi Hasil Penyaringan yang Digunakan

\begin{tabular}{ccccc}
\hline No & POSITIF & PDP & ODP & STATUS \\
\hline 1 & Sangat Rendah & Sangat Rendah & Sangat Rendah & HIJAU \\
2 & Sangat Rendah & Sangat Rendah & Rendah & BIRU \\
3 & Sangat Rendah & Sangat Rendah & Sedang & BIRU \\
4 & Sangat Rendah & Sangat Rendah & Tinggi & BIRU \\
5 & Sangat Rendah & Sangat Rendah & Sangat Tinggi & KUNING \\
6 & Sangat Rendah & Rendah & Sangat Rendah & BIRU \\
7 & Sangat Rendah & Rendah & Rendah & BIRU \\
8 & Sangat Rendah & Rendah & Sedang & BIRU \\
$\ldots$ & $\ldots$ & $\ldots$ & $\ldots$ & $\ldots$ \\
124 & Sangat Tinggi & Sangat Tinggi & Tinggi & KUNING \\
125 & Sangat Tinggi & Sangat Tinggi & Sangat Tinggi & KUNING \\
\hline
\end{tabular}

c. Penyelesaian Model Menggunakan Matlab

Gambar 6 merupakan tampilan jendela Toolbox Matlab untuk proses Mamdani, aturan implikasi yang digunakan adalah Minimum sedangkan metode penggabungan atau agregasinya adalah Maksimum. Selain itu, untuk deffuzyfikasinya sendiri menggunakan metode Centroid. 


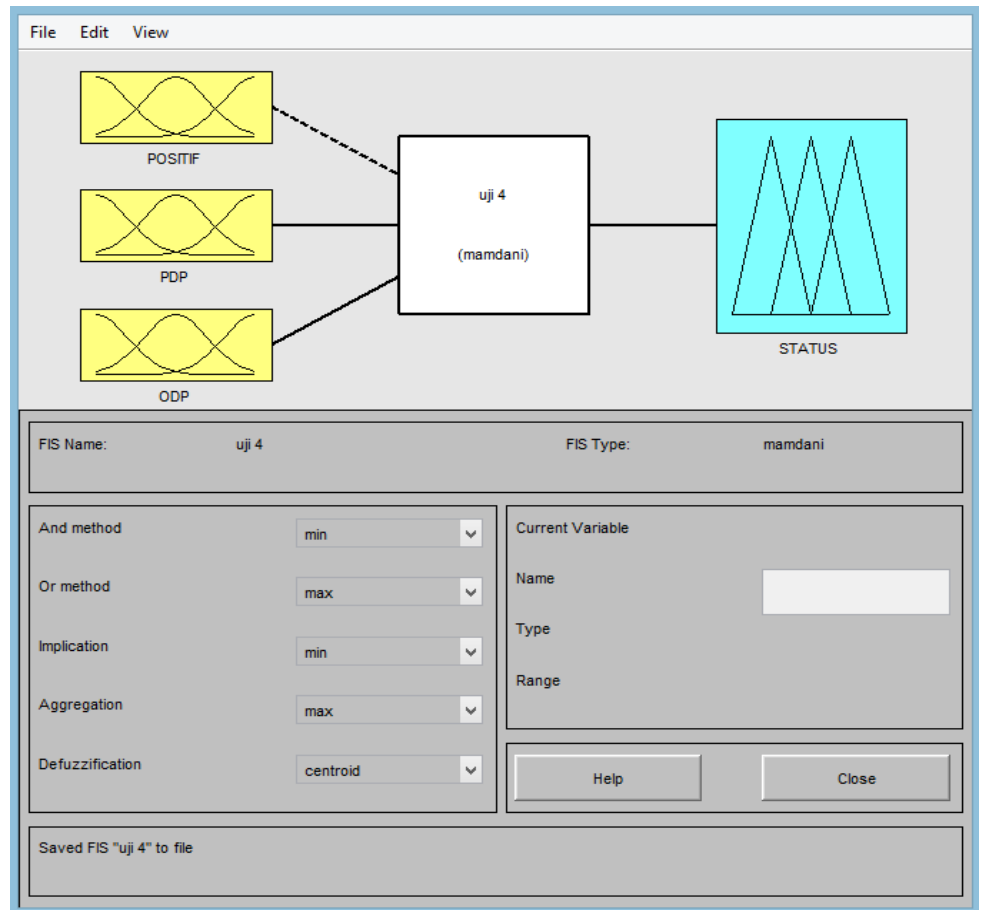

Gambar 6. Model FIS Mamdani pada Fuzzy Toolbox

d. Hasil Implementasi Model Terhadap Data

Implementasi model juga dilakukan terhadap beberapa wilayah, salah satunya Kabupaten Bogor. Hasil implementasi model terhadap data COVID-19 di kabupaten Bogor disajikan pada Tabel 6.

Tabel 6. Sebagian data Input dan Output Hasil Implementasi Model pada Data Kabupaten Bogor

\begin{tabular}{cccccccc}
\hline No. & Tanggal & Positif & PDP & ODP & Status Real & Hasil FIS Mamdani & Status (Hasil FIS Mamdani ) \\
\hline 1 & 01-Apr-20 & 18 & 122 & 371 & BIRU & 3,48 & BIRU \\
2 & 02-Apr-20 & 22 & 122 & 371 & BIRU & 3,48 & BIRU \\
3 & 03-Apr-20 & 23 & 237 & 408 & BIRU & 3,48 & BIRU \\
4 & 04-Apr-20 & 25 & 258 & 251 & BIRU & 3,32 & BIRU \\
5 & 05-Apr-20 & 27 & 259 & 255 & BIRU & 3,33 & BIRU \\
6 & 06-Apr-20 & 27 & 259 & 255 & BIRU & 3,33 & BIRU \\
7 & 07-Apr-20 & 27 & 325 & 324 & BIRU & 3,62 & BIRU\& KUNING \\
$\ldots$ & $\ldots$ & $\ldots$ & $\ldots$ & $\ldots$ & $\ldots$ & $\ldots$ & $\ldots$ \\
106 & 15-Jul-20 & 245 & 191 & 55 & KUNING & 3.26 & BIRU \\
\hline
\end{tabular}

Dari Tabel 6, terlihat bahwa ada beberapa hasil yang menunjukan bahwa wilayah Kabupaten Bogor masuk pada dua status kewaspadaan sekaligus. Oleh karena itu, dihitung derajat keanggotaannya di kedua himpunan Fuzzy status kewaspadaan yang bersangkutan. Kemudian, dari hasil derajat keanggotaan tersebut, didapatkan status kewaspadaan akhir yang akan digunakan untuk perbandingan dengan data real. Hasil perhitungan tersebut disajikan pada Tabel 7.

Tabel 7. Beberapa Hasil Perhitungan Derajat Keanggotaan Kab.Bogor

\begin{tabular}{|c|c|c|c|c|c|c|}
\hline No. & Tanggal & Hasil FIS Mamdani & Status (Hasil FIS Mamdani ) & \multicolumn{2}{|c|}{ Derajat Keanggotaan } & Status Akhir \\
\hline 1 & 01-Apr-20 & 3,48 & BIRU & \multicolumn{2}{|c|}{0,580} & BIRU \\
\hline 2 & $02-A p r-20$ & 3,48 & BIRU & \multicolumn{2}{|c|}{0,580} & BIRU \\
\hline 3 & 03-Apr-20 & 3,48 & BIRU & \multicolumn{2}{|c|}{0,580} & BIRU \\
\hline 4 & 04-Apr-20 & 3,32 & BIRU & \multicolumn{2}{|c|}{0,673} & BIRU \\
\hline 5 & 05-Apr-20 & 3,33 & BIRU & \multicolumn{2}{|c|}{0,671} & BIRU \\
\hline 6 & 06-Apr-20 & 3,33 & BIRU & \multicolumn{2}{|c|}{0,671} & BIRU \\
\hline 7 & 07-Apr-20 & 3,62 & BIRU \& KUNING & 0,502 & 0,069 & BIRU \\
\hline 8 & 08-Apr-20 & 3,87 & BIRU \& KUNING & 0,361 & 0,211 & BIRU \\
\hline$\ldots$ & $\ldots$ & $\ldots$ & $\ldots$ & $\ldots$ & $\ldots$ & $\ldots$ \\
\hline 106 & 15-Jul-20 & 3.26 & BIRU & \multicolumn{2}{|c|}{0,709} & BIRU \\
\hline
\end{tabular}

Untuk dapat melihat tingkat keberhasilan model yang telah dibuat, maka dilakukan perbandingan antara status kewaspadaan COVID-19 hasil FIS Mamdani akhir dan status kewaspadaan 
Jurnal Sains dan Edukasi Sains, Vol.4, No.1, Februari 2021: 28-39

COVID-19 real yang ditentukan pemerintah. Tabel 8 akan menunjukkan rangkuman perbandingan tersebut :

Tabel 8. Perbandingan Data Real dan Data Hasil FIS Mamdani Kab.Bogor

\begin{tabular}{|c|c|c|c|c|}
\hline \multirow{2}{*}{ Tanggal } & \multicolumn{2}{|c|}{ Status Kewaspadaan } & \multirow{2}{*}{ Kesamaan } & \multirow{2}{*}{ Jumlah Data } \\
\hline & Real & FIS Mamdani & & \\
\hline 1 April - 30 April & BIRU & BIRU & Sama & 30 \\
\hline $1 \mathrm{Mei}$ & KUNING & BIRU & Beda & 1 \\
\hline 2 Mei - 4 Juni & KUNING & KUNING & Sama & 34 \\
\hline 5 Juni - 6 Juni & KUNING & BIRU & Beda & 2 \\
\hline 7 Juni -8 Juli & KUNING & KUNING & Sama & 3 \\
\hline 9 Juli -15 Juli & KUNING & BIRU & Beda & 7 \\
\hline
\end{tabular}

Kemudian dari data tersebut, dapat dihitung persentase kesamaan status dengan data real menggunakan persamaan 2. Hasil perhitungan menunjukkan bahwa persentase kesamaan antara data real status kewaspadaan COVID-19 dengan data hasil uji FIS Mamdani adalah sekitar 90,56 \%. Hal ini menunjukkan bahwa model yang dibuat sudah cukup bagus untuk membantu dalam menentukan status kewaspadaan di wilayah Bogor.

e. Rangkuman Hasil Implementasi Data

Tabel 9 menunjukkan rangkuman dari persentase kesamaan status antara hasil analisis menggunakan pemodelan FIS Mamdani dengan data real, pada 4 (empat) kali pengulangan hingga diperoleh nilai rata-rata kesamaan status adalah $81,1 \%$.

Tabel 9. Persentase Kesamaan di tiap Pengulangan Analisis Data

\begin{tabular}{ccccc}
\hline \multirow{2}{*}{ WILAYAH } & \multicolumn{4}{c}{ Analisis (Implementasi Model pada Data) } \\
\cline { 2 - 5 } & ANALISIS 1 & ANALISIS 2 & ANALISIS 3 & ANALISIS 4 \\
\hline Kab. Bogor & $60,6 \%$ & $70,75 \%$ & $83,01 \%$ & $90,56 \%$ \\
Kota Depok & $80,5 \%$ & $72,64 \%$ & $76,4 \%$ & $88,67 \%$ \\
Kota Bandung & $48,1 \%$ & $57,54 \%$ & $77 \%$ & $80,1 \%$ \\
Kab. Cianjur & $64,1 \%$ & $63,2 \%$ & $76,4 \%$ & $71,6 \%$ \\
Kab.Garut & $19,8 \%$ & $14,1 \%$ & $61,3 \%$ & $83,01 \%$ \\
Kota Bekasi & $60,3 \%$ & $64 \%$ & $76,4 \%$ & $72 \%$ \\
\hline Rata-rata & $\mathbf{5 5 , 5 6 \%}$ & $\mathbf{5 7 , 0 3} \%$ & $\mathbf{7 5 , 0 8 \%}$ & $\mathbf{8 1 , 1 \%}$ \\
\hline
\end{tabular}

\section{Pembahasan}

Dari Tabel 9, dapat diketahui bahwa pada analisis pertama didapatkan rata-rata persentase kesamaan dengan data real di 6 wilayah hanya sebesar 55,56\%. Karena rata-rata persentasenya masih belum mencapai $80 \%$, maka penelitian dilanjutkan dengan analisis yang kedua.

Pada analisis kedua, dilakukan perubahan terhadap domain beberapa himpunan Fuzzy di tiap variabel, dengan cara memperlebar interval domainnya. Setelah itu, dilakukan implementasi model yang baru terhadap data yang sama. Analisis kedua ini menghasilkan rata-rata persentase kesamaan dengan data real sebesar $57,3 \%$, dimana terdapat kenaikan sebesar $1,47 \%$ dari persentase pada analisis sebelumnya. Meskipun terdapat kenaikan, namun persentase kesamaan pada analisis kedua ini juga belum bisa dikatakan optimal karena belum mencapai indikator $80 \%$, sehingga harus dilakukan analisis kembali.

Pada analisis ketiga, perubahan dilakukan dengan memperlebar dan mempersempit interval beberapa himpunan Fuzzy. Setelah dilakukan implementasi model yang baru terhadap data kembali, didapatkan rata-rata persentase kesamaan dengan data real sebesar 75,08\%. Jika dibandingkan dengan hasil persentase pada analisis sebelumnya, maka terdapat kenaikan yang cukup besar, yakni $17,73 \%$. Meskipun analisis ketiga ini memberikan hasil yang cukup baik, tetapi harus dilakukan analisis data kembali karena persentase kesamaan yang didapat masih belum mencapai indikator $80 \%$.

Pada analisis yang keempat, perubahan yang dilakukan adalah dengan kembali memperlebar beberapa interval domain himpunan Fuzzy yang digunakan. Setelah dilakukan implementasi model, didapatkan hasil rata-rata persentase kesamaan dengan data real sebesar $81,1 \%$ yang mengindikasikan bahwa model yang digunakan sudah optimal karena sudah mencapai indikator $80 \%$. Oleh karena itu, proses analisis dihentikan, karena Model FIS Mamdani pada analisis keempat ini dapat dikatakan optimal.

Melalui beberapa analisis ini juga dapat diketahui bahwa dari implementasi model FIS terhadap data, terdapat hasil yang menunjukkan bahwa suatu wilayah dapat masuk ke dalam dua status kewaspadaan sekaligus, yang kemudian dicari derajat keanggotaannya untuk menentukan status 
kewaspadaan mana yang diambil dengan melihat derajat keanggotaan yang lebih tinggi. Akan tetapi, masuknya suatu wilayah pada dua status kewaspadaan tidak dapat diabaikan. Hal ini dapat digunakan untuk penyesuaian kebijakan. Salah satu kebijakan yang dapat diberikan penyesuaian adalah kebijakan pemerintah untuk setiap status kewaspadaan seperti yang diatur pada Peraturan Gubernur Jawa Barat No.46 Tahun 2020 tentang Pedoman PSBB Sesuai Level Kewaspadaan Daerah Kabupaten/Kota.

Sebagai contoh, pada status kewaspadaan BIRU, aktivitas perbankan hanya memiliki waktu operasional pukul 08.00 sampai 14.00 , dengan kapasitas pegawai yang dapat bekerja di kantor hanya $50 \%$, sedangkan sisanya harus Work From Home. Kemudian untuk status kewaspadaan KUNING, aktivitas perbankan hanya memiliki waktu operasional pukul 08.00 sampai 12.00,dengan kapasitas pegawai yang dapat bekerja di kantor hanya $25 \%$. Kemudian dapat dilakukan penyesuaian untuk di wilayah yang memiliki status kewaspadaan BIRU dan KUNING sekaligus, misalnya Kabupaten Bogor. Contoh penyesuaiannya adalah waktu operasional perbankan sama seperti status kewaspadaan KUNING yaitu 08.00 sampai 12.00 , namun untuk kapasitas pegawainya sama seperti status kewaspadaan BIRU yaitu $50 \%$.

Dalam penelitian ini, metode FIS Mamdani ternyata dapat memberikan hasil yang cukup baik untuk menentukan status kewaspadaan COVID-19 berdasarkan data input, yaitu data harian dari kasus positif COVID-19, PDP, dan ODP. Hal ini diperkuat oleh penelitian-penelitian pendukung yang sudah dijelaskan sebelumnya, meskipun pada penelitian tersebut diterapkan untuk data/obyek yang berbeda. Pada ketiga penelitian ini bertujuan menggunakan metode Fuzzy Inference System Mamdani untuk menilai dan memberikan status berbentuk level atau tingkatan pada suatu wilayah berdasarkan faktor-faktor yang berpengaruh untuk digunakan sebagai data input. Dengan kata lain, metode FIS Mamdani cocok untuk menyelesaikan permasalahan yang berhubungan dengan penentuan status level atau tingkatan dari suatu wilayah berdasar situasi dan kondisi yang terjadi.

\section{KESIMPULAN}

1. Metode Fuzzy Inference System (FIS) Mamdani dapat digunakan untuk menentukan status kewaspadaan COVID-19 pada beberapa wilayah di Jawa Barat dengan rata-rata persentase kesamaan status dengan data real sebesar $81,1 \%$.

2. Model FIS Mamdani optimal yang diperoleh pada analisis keempat, memiliki atribut sebagai berikut :

a. Variabel Input : POSITIF, PDP, dan ODP, dan masing-masing mempunyai 5 himpunan Fuzzy yaitu Sangat_Rendah, Rendah, Sedang, Tinggi, Sangat_Tinggi.

b. Variabel Output Status_Kewaspadaan yang mempunyai 5 himpunan Fuzzy, yakni HIJAU, BIRU, KUNING, MERAH, dan HITAM.

c. Menggunakan 125 aturan implikasi.

\section{UCAPAN TERIMA KASIH}

Ucapan terimakasih diberikan kepada Dinas Kesehatan, Dinas Komunikasi dan Informasi, dan seluruh Pemerintah Provinsi Jawa Barat yang senantiasa menyediakan informasi mengenai perkembangan pandemi COVID-19 dan mempublikasikan data-data penting mengenai COVID-19 yang sangat berguna bagi penelitian ini.

\section{DAFTAR PUSTAKA}

Arifin, S., Muslim, M. A., \& Sugiman, S. (2016). Implementasi Logika Fuzzy Mamdani untuk Mendeteksi Kerentanan Daerah Banjir di Semarang Utara. Scientific Journal of Informatics, 2(2), 179. https://doi.org/10.15294/sji.v2i2.5086

John Hopkins University \& Medicine. (2020). COVID-19 Map - Johns Hopkins Coronavirus Resource Center. Retrieved September 13, 2020, from https://coronavirus.jhu.edu/map.html

Kusumadewi, S., \& Purnomo, H. (2010). Aplikasi Logika Fuzzy untuk pendukung keputusan. Yogyakarta: Graha Ilmu, 33-34.

Niemiec, M. (2017). Fuzzy inference system: theory and applications. Scitus Academics LLC, Wilmington.

Setiadji, S. (2009). Himpunan \& Logika Samar serta aplikasinya. Yogyakarta: Graha Ilmu. 
Shen, C., Bar-yam, Y., \& New England Complex Systems Institute. (2020). Color Zone Pandemic Response Version 2. 2020. Retrieved from https://necsi.edu/color-zone-pandemic-response-version-2

Susilo, A., Rumende, C. M., Pitoyo, C. W., Santoso, W. D., Yulianti, M., Herikurniawan, H., ... Nelwan, E. J. (2020). Coronavirus Disease 2019: Tinjauan Literatur Terkini. Jurnal Penyakit Dalam Indonesia, 7(1), $45-67$.

Tuwu, D. (2020). Kebijakan Pemerintah Dalam Penanganan Pandemi Covid-19. Journal Publicuho, 3(2), 267278. https://doi.org/10.35817/jpu.v3i2.12535

Yenni, Y., \& Utnasari, I. (2019). Fuzzy Logic Mamdani Memprediksi Tingkat Kriminalitas. Prosiding Seminar Nasional IImu Sosial Dan Teknologi (SNISTEK), 2, 247-252. n.

Zadeh, L. A. (1965). Fuzzy sets. Information and Control, 8(3), 338-353. 